\title{
Saugumo politikos kelio pabaiga? Švedijos ir Suomijos vaidmuo Šiaurès ir Baltijos šalių bendradarbiavime gynybos srityje
}

Straipsnis nagrinèja Šiaurès ir Šiaurès-Baltijos šalių bendradarbiavimą gynybos srityje. Pirmiausia aptariama, kiek toli šiandien yra pažengęs šis Šiaures ir Šiaurès-Baltijos šalių bendradarbiavimas. Antra, kokie yra Švedijos ir Suomijos požiūrių skirtumai, kai kalba eina apie bendradarbiavimą gynybos srityje Šiaurès-Baltijos regione su NATO. Pirma analitine išvada, kurios prieinama straipsnyje yra ta, kad Šiaures ir Šiaurès-Baltijos šalių bendradarbiavimo gynybos srityje retorika yra raiškesnè negu realūs pasiekimai. Antra, panašu ị tai, kad Švedijos ir Suomijos debatai dèl saugumo ir gynybos politikos yra ganètinai skirtingi. Nors kai kurios debatuose išryškejjusios problemos yra panašios, tačiau siūlomi jų sprendimai esmingai skiriasi. Esminis skirtumas slypi tame, kad Švedijos politinis elitas lygiai kaip ir viešoji nuomonè pradeda iš esmès labai rimtai svarstyti galimą šalies narystę NATO. Tuo tarpu kol kas nieko panašaus negalima pasakyti apie Suomiją.

\section{Ivadas}

Šiaurès šalių, kartais Šiaurès ir Baltijos šalių bendradarbiavimas gynybos srityje šiandien yra svarbiausias „budinti“ sąvoka tiek Švedijos, tiek Suomijos saugumo politikos diskusijose. Ji išreiškia ekonominio efektyvumo ir saugumo ir (ar) gynybos integracijos idejas, nors didele dalis jos strateginių pasekmių niekada išsamiai neatskleidžiamos.

Todèl būtų teisinga paklausti daug klausimų, susijusių su visomis šiomis sąvokomis. Pirmiausia, kaip toli Šiaurès šalių ir Šiaurès ir Baltijos šalių bendradarbiavimas gynybos srityje yra pažengęs? Ir kaip toli jis pažengs ateityje? Siekiant atsakyti $\mathfrak{i}$ šiuos klausimus, reikia nuodugniai išsiaiškinti, koks ben-

\footnotetext{
* Dr. Mike’as Winnerstigas yra Karališkosios Švedijos karo mokslų akademijos narys ir šiuo metu Švedijos gynybos tyrimų agentūros direktoriaus pavaduotojas, atsakingas už mokslinius tyrimus. Adresas korespondencijai: Swedish Defence Research Agency, SE-16490 Stockholm, Sweden; phone +46-8-55503000, el. paštas: mike.winnerstig@foi.se

** Šiame straipsnyje pateikti vertinimai yra be išimčių tik autoriaus ir jokiu būdu neatspindi Švedijos gynybos tyrimų agentūros, Švedijos gynybos ministerijos ar Švedijos vyriausybès požiūrio.
} 
dradarbiavimas gynybos srityje klostosi tarp Šiaurès ir Baltijos šalių šiandien. Pavyzdžiui, ar stiprus yra Šiaurès ir Baltijos šalių bendradarbiavimas gynybos srityje palyginti su vien tik Šiaurès šalių bendradarbiavimu?

Antra, Švedija ir Suomija išsiskiria Šiaurès ir Baltijos šalių kontekste, nes jos yra ES, bet ne NATO narès. Visos kitos susijusios šalys yra abiejų organizacijų narès (išskyrus Norvegiją ir karine prasme nesvarbią Islandiją, kurios nèra ES narès). Bet ar yra skirtumų šių dviejų šalių požiūriuose, kai kalbama apie bendradarbiavimą gynybos srityje Šiaurès ir Baltijos šalių regione?

Šie klausimai yra pagrindinès problemos, pateikiamos šiame straipsnyje, kuriame remiamasi keliomis autoriaus anksčiau atliktomis tų pačiu temų analizèmis.

Pirmiausia ir be išsamesnės analizės akivaizdu, kad retorinis Šiaurės šalių ir Šiaurès ir Baltijos šalių bendradarbiavimo gynybos srityje proceso pagrindas yra didesnis negu realūs pasiekimai, ypač gynybos integracijos požiūriu.

Antra, taip pat atrodo aišku, kad Švedijos ir Suomijos gynybos ir saugumo politikos debatai yra visiškai skirtingi. Kai kurios, nustatytos debatuose problemos šiose abiejose šalyse yra labai panašios, nors jų pasiūlyti sprendimo būdai nepaprastai skiriasi. Kalbant apie esminį narystès NATO klausimą, pastarųjų kelerių metų ịvykiai rodo, kad politinis Švedijos elitas ir plačioji visuomenè yra arčiau realios diskusijos dèl narystės NATO negu jų atitikmenys Suomijoje.

\section{1. Švedija, Suomija ir Šaltojo karo palikimas}

Šaltojo karo metu ir Švedija ir Suomija galejo visiškai oficialiai teigti, dažnai remdamosi vadinamąja neutraliteto politika, kad kitų šalių sąveikos ar konfliktai Baltijos jūros regione jų neliečia. Beveik per visą Šaltojo karo laikotarpị, Švedijos oficialiai ir atvirai išdėstytas saugumo politikos tikslas buvo išvengti Švedijos ịsitraukimo ị bet kokị jos kaimynysteje pasireiškusị konfliktą. Todèl būtų galima teigti, kad Baltijos jūros regionas per Šaltąji karą buvo ne daugiau, kaip to paties Šaltojo karo geopolitikos tęsinys, o Švedija ir Suomija figūravo tik kaip buferinès zonos tarp dviejų karinių blokų Europoje.

Šiandien, praejjus beveik 20 metų po Šaltojo karo, situacija yra iš esmès pasikeitusi. Baltijos jūros regione yra daugybė sąveikos atvejų; ekonominiai ir politiniai ryšiai užmezgami labai greitai; verslo santykiai, buvę visiškai neịmanomi ar net neįsivaizduojami Šaltojo karo metu - pavyzdžiui, ypač svarbus dabartinis Švedijos bankų vaidmuo visose trijose Baltijos šalių ekonomikose jau realūs. Reikia pripažinti, kad gynybos sritis yra daug mažiau išplètota negu 
ekonomikos, bet Baltijos valstybėms ịsijungus ị NATO 2004 metais, daugiau negu pusė Skandinavijos šalių dabar yra karine prasme taip pat susijusios su savo Baltijos jūros kaimynemis. Tačiau per keletą paskutiniųjų metų kariniai klausimai kaip tik yra tie (nors ne vien tik tie), kurie sukèle didelę trintị tarp Rusijos iš vienos pusès ir regiono NATO sajungininkių iš kitos. NATO planai ịrengti priešraketinès gynybos elementus Lenkijoje ir nediplomatiškos Rusijos karinès pratybos „Zapad“ 2009 m. ir 2013 m. yra tos problemos, kurios, švelniai tariant, lèmé didelę įtampą. ${ }^{1}$

Tai taip pat buvo pagrindas pradèti esminę diskusiją dèl Rusijos vaidmens Baltijos jūros regione. Švedijos diskusijose ypač daug dèmesio buvo skirta kai kurioms neseniai vykdytoms karinems Rusijos pratyboms, kurių metu buvo imituojamos kelios oro atakos prieš Švediją. ${ }^{2}$ Kadangi Švedijos visuomenès nuomone yra be išlygų viena iš labiausiai skeptiškų Rusijos atžvilgiu visoje Europos Sąungoje, Šaltojo karo sentimentų atgaivinimas pastaruoju metu buvo gana ịprastas. Naujausioje Transatlantic Trends nuomonės apklausoje, kurią atliko Vokietijos Marshallo fondas, net 76 \% Švedijos gyventojų vertino Rusiją nepalankiai ir tai yra didžiausias skaičius iš 13 apklausoje dalyvavusių šalių. ${ }^{3}$ Suomija apklausoje nedalyvavo, nors yra paplitusi nuomonè, kad suomių požiūris ị Rusiją mažiau negatyvus, bet jis yra sudètingas dèl didesnès ekonominès integracijos proceso ir didejančios emigrantų iš Rusijos svarbos Suomijos visuomeneje. ${ }^{4}$

\footnotetext{
${ }^{1}$ Apie raketinę gynybą žr., pvz. Anders Lennartsson \& Fredrik Lindvall (2011): USAs bidrag till NATO:s missilförsvar [The US Contribution to the NATO Missile Defence System], FOI-R--3226-SE (Stockholm: FOI Defence Analysis]. Apie Rusijos pratybas žr., pvz., Roger McDermott (2009), Zapad 2009 Rehearses Countering a NATO Attack on Belarus, Jamestown Foundation, http://www.jamestown.org /single/?no_ cache $=1 \&$ tx_ttnews $\% 5 B t t \_n e w s \% 5 D=35558$.

${ }^{2}$ Žr. pvz. Mikael Holmström (2013): "Ryskt flyg övade anfall mot Sverige" [Russian air forces exercised attacking Sweden], Svenska Dagbladet, balandžio 22 d. (http://www.svd.se/nyheter/inrikes/ryskt-flyg-ovadeanfall-mot-sverige_8108894.svd) ir Olle Lönnaeus (2013), "Het militärhöst runt Östersjön" ["Hot military autumn around the Batltic Sea", Sydsvenska Dagbladet, rugsèjis, lapkričio 9 d., http://www.sydsvenskan.se/ sverige/het-militarhost-runt-ostersjon/.

${ }^{3}$ Žr. German Marshall Fund of the United States (2013): Country Profile: Sweden, (http://trends.gmfus. org/ transatlantic-trends/country-profiles-2/sweden/).

${ }^{4}$ Richard Milne (2013): "Finns eye growing Russian presence with apprehension", Financial Times spalio 31 d., http://www.ft.com/intl/cms/s/0/1934c268-407b-11e3-ae19-00144feabdc0.html\#axzz2jUxxIUqX.
} 


\section{2. Šiaurès ir Baltijos šalių bendradarbiavimas gynybos srityje ir ŠB8 koncepcija ${ }^{5}$}

Vis tik, nepaisant i̇vairaus Šaltojo karo palikimo, Šiaurès šalių ir (ar) Šiaurès ir Baltijos šalių bendradarbiavimo gynybos srityje koncepcija yra populiari tema tiek Švedijoje, Suomijoje, tiek Baltijos valstybèse.

Šiaurès šalių bendradarbiavimas ilgą laiką buvo labai svarbus Šiaurès šalyse, pavyzdžiui, Šiaurès Taryba gyvuoja nuo 1952 m., tačiau jos veikla gynybos srityje siekia daug vèlesnius laikus, kadangi Šiaurès Tarybai nuo pat pradžių nebuvo leista spręsti gynybos ir saugumo klausimų.

Šiaurès ir Baltijos šalių aštuonetas (ŠB8) yra palyginti sena sąvoka. Jau pirmajj 1990 m. dešimtmeti, po Baltijos šalių nepriklausomybès atkūrimo proceso, šios aštuonios šalys pradèjo įvairių lygių susitikimus viena su kita, bet daugelį metų ta veikla buvo, visų pirma, organizuojama jų užsienio reikalų ministrų, o svarstomi klausimai nebuvo tiesiogiai susiję su gynybos problemomis.

Šiandien, kai kalbama apie Šiaurès šalis ir dabartinę jų saugumo ir gynybos politiką, akivaizdus paradoksas. Nors dažnai manoma, kad šios penkios šalys pasižymi panašia politika ir kultūriniu ir socialiniu bendrumu, tačiau nẻ viena iš jų nevykdo saugumo politikos, kuri būtų identiška bet kuriai kitai Šiaurès šaliai. Islandija yra NATO, bet ne ES nare ir neturi savo gynybinių pajègų. Norvegijos narystès situacija yra tokia pati, bet ji turi stiprias gynybines pajègas, glaudžiai susijusias su Jungtinemis Amerikos Valstijomis ir Jungtine Karalyste, ypač laivyno požiūriu. Danija yra ir NATO ir ES narè, bet nusišalina, kai svarstoma dar nauja ES gynybos dimensija ir euras. Švedija yra ES narè ir labai aktyviai dalyvauja ES gynybinejje veikloje, bet atsisake įsivesti eurą ir nèra NATO narè. Suomija yra ES nare ir ịsivedè eurą, iš esmès labiau integruodama šali i ES, bet, vélgi, nèra NATO narè.

Priešingai Šiaurès šalių nevienalytiškumui gynybos integracijos srityje, Baltijos valstybės yra nepaprastai vienodos: visos jos yra ir NATO ir ES narès. Todèl būtų teisinga sakyti, kad visos Baltijos šalys yra tikrai labiau integruotos ¡̇ bendrąją euroatlantinę saugumo sistemą negu bet kuri iš jų Šiaurès kaimynių. Svarbu nepamiršti šių ryšiu, svarstant ŠB8 gynybinès integracijos ateitị.

\footnotetext{
${ }^{5}$ Ši dalis daug remiasi Mike Winnerstig (2012): Defence Integration in the Baltic Sea Security Complex- A Conceptual Approach, iš Kurt Volker ir Ieva Kupce (eds.): Nordic-Baltic-American Cooperation: Shaping the US-European Agenda, (Washington, DC: SAIS/JHU - Center for Transatlantic Relations).
} 


\section{3. ŠB8 bendradarbiavimo gynybos srityje plètra}

Kaip minèta anksčiau, Baltijos valstybės - bent jau po 2004 m. - yra, iš esmès, integruotos ị didžiausias tarptautines saugumo organizacijas, tokias kaip NATO ir ES. Tačiau, dèl savo dydžio ir to fakto, kad teritorinès gynybos klausimai buvo NATO Aljanse labai nepopuliarūs prieš Rusijos ir Gruzijos $2008 \mathrm{~m}$. karą, praktinis to rezultatas, galbūt, buvo ne toks geras, kokio Baltijos valstybès tikejjosi, bent jau iki $2010 \mathrm{~m}$. Tais metais, remiantis spaudos pranešimais, oficialiais pareiškimais ir Wikileaks paviešintais dokumentais, NATO prièmè visaverčius Baltijos valstybių teritorinès gynybos planus. ${ }^{6}$ Nors dèl praktinès šių planų reikšmès kyla tam tikrų klausimų, turint omenyje NATO karinių pajègų Europoje mažinimą, pats jų buvimo faktas leidžia manyti, kad Baltijos valstybès, kartu su savo Šiaurès sąungininkèmis, karine prasme yra akivaizdžiai integruotos ị NATO gynybos sistemą.

Tačiau ir nevienalytiška ŠB8 dalis - Šiaurès šalys keletą kartų bandè padidinti bendradarbiavimą gynybos srityje. Vadinamoje Stoltenbergo ataskaitoje, parengtoje buvusio Norvegijos užsienio reikalų ministro Thorvaldo Stoltenbergo ir paskelbtoje 2009 metais pateikta daug konkrečiu pasiūlymų, kaip padidinti bendradarbiavimą ir užsienio, ir saugumo politikos srityse tarp Šiaurès valstybių, ịskaitant ir tam tikras visų penkių valstybių tarpusavio gynybos garantijas. ${ }^{7}$ Iš dalies dèl pastarojo pasiūlymo, Stoltenbergo ataskaita viešame šių šalių diskurse plačiai nebuvo svarstoma.

Tačiau tais pačiais metais keletas kitų svarbių ìvykių paveike Šiaurès valstybiu gynybos problemą. ES ịsigaliojo Lisabonos sutartis, o kartu su ja buvo priimti ir dviejų rūšiu savitarpio pagalbos punktai; visų pirma, solidarumo punktas, susijęs su pagalba teroristinès atakos, stichinès nelaimès ar panašiu atveju valstybëje nareje (2.1.2straipsnis), antrasis buvo tradicinis gynybinès pagalbos punktas, panašus ị Šiaurès Atlanto sutarties 5 straipsnị (42.7 straipsnis). Dèl to, kad sutartyje buvo įtvirtinta nuostata, kad ES narès, kurios kartu yra NATO narès, gynybos požiūriu laikysis NATO susitarimų, ES kaip karinio aljanso sąvoka netapo aktuali. Vis dèlto, ji sukèlè diskusiją apie gynybą ir solidarumą ir Švedijoje, ir Suomijoje.

Iš dalies dèl to $2009 \mathrm{~m}$. vasarą Švedijos parlamentas prièmè labai svarbų

\footnotetext{
${ }^{6}$ Žr. pvz., Bo Ljung, Tomas Malmlöf, Karlis Neretnieks \& Mike Winnerstig (2012): The Security and Defensibility of the Baltic States - a Comprehensive Analysis (Stockholm: FOI Defence Analysis), ypač 3 ir 4 skyriai.

${ }^{7}$ Žr. Thorvald Stoltenberg (2009): Nordic Cooperation On Foreign and Security Policy: Proposals presented to the extraordinary meeting of Nordic foreign ministers in Oslo on 9 February 2009, http://www. regeringen.se/content/1/c6/12/01/83/94662dc3.pdf.
} 
gynybos ịstatymą. Šiame ịstatyme ịtvirtinti du itin svarbūs Švedijos saugumo politikos pokyčiai. Pirma, visiškai priešingai svarbiausiems Švedijos saugumo politikos doktrinos principams, galiojusiems nuo XIX amžiaus pradžios, vyriausybė pareiškė, kad Švedija neliks pasyvi, jei nelaimė ar užpuolimas ištiktų kitą ES valstybę narę arba Šiaurès šalį ir, kad Švedija tikisi, kad šios šalys pasielgtų taip pat, jei Švedija būtų užpulta. Antra, siekdama pakelti tai ị operatyvinị lygmenị, vyriausybė skyrè užduotị Švedijos ginkluotosioms pajègoms būti pasiruošusioms ir suteikti, ir priimti karinę pagalbą. ${ }^{8}$ Abi šios temos - būti paveiktai užpuolimų prieš kitas valstybes ir gebèti suteikti joms karinę pagalbą, taip pat gauti pagalbą iš jų atakos prieš Švediją atveju - su nedidelèmis išimtimis, nuo $1812 \mathrm{~m}$. buvo draudžiama tema Švedijos saugumo politikos formuotojams. Ypatingas šios naujosios doktrinos bruožas - Švedijoje pavadintas „Solidarumo deklaracija“ - yra vienašališkas jos charakteris; ją paskelbdama, Švedija iš nieko neprašè analogiško issipareigojimo ir atrodè, kad vietoj to pasikliauja tuo, kad kitos šalys suteiks Švedijai pagalbą be jokio oficialaus išankstinio pritarimo šiai doktrinai. Naujoji doktrina sukèlè negausius viešus kritiškus komentarus Švedijoje, ypač kai kurių tradicinès neutralumo politikos apologetų, ${ }^{9}$ bet apskritai buvo priimta be didelių fanfarų ir, reikètų pridèti, pateikiant visuomenei daug informacijos apie doktrinos pokyčius. Kadangi instatyme taip pat numatyta didelès gynybos reformos struktūra, tarp jų privalomos karinès tarnybos "užšaldymas“ ir vietoj jos suformavimas nedidelių vien savanoriškų pajègų, apimančių maždaug 10 \% per Šaltąji karą turètų žmogiškųjų resursų, jo turinys faktiškai buvo revoliucingas. ${ }^{10}$

Suomijoje, kitokioje gynybos politikos požiūriu ŠB8 grupès šalyje, analogiška doktrina nebuvo priimta, nors Suomija oficialiai ir tvirtai prisidejo prie ES Lisabonos sutarties solidarumo ir gynybos punktų.

Be to, dar neturintis didelès patirties Šiaurès šalių bendradarbiavimas gynybos įrangos ir susijusiais klausimais, kuris ad hoc būdu vyko daugelį metų, 2009 m., ịkūrus NORDEFCO (Šiaurès šalių bendradarbiavimo gynybos srityje organizacija) iggavo labiau institucionalizuotą pobūdị. Pagrindinis šio bendra-

\footnotetext{
${ }^{8}$ Ministry of Defence (2009), A Useful Defence, The Swedish Government’s Bill 2008/09:140, esp. p. 9. Žr. http://www.regeringen.se/content/1/c6/12/29/57/853ca644.pdf.

${ }^{9}$ Žr. pvz., Mikael Nilsson (2009), "Ny doktrin sätter freden på spel" [New Doctrine Puts Peace at Risk], Svenska Dagbladet, Dec. $2^{\text {nd }}$, http://www.svd.se/opinion/brannpunkt/ny-doktrin-satter-freden-paspel_3878379.svd.

${ }^{10} 2011 \mathrm{~m}$. Karališkoji Švedijos karo mokslų akademija išspausdino svarbią studiją apie solidarumo deklaraciją, kuri po metų buvo išspausdinta ir anglų kalba. Šioje studijoje be kitų dalykų buvo pateikta keletas kritinių analizių apie praktines galimybes karine prasme išlaikyti solidarumo deklaracijoje žodžiais neišreikštus pažadus, bet kol kas nesulauke didelio visuomenès dèmesio. Žr. Bo Hugemark. ed., (2012): Friends in Need: Towards a Swedish Strategy of Solidarity with her Neighbours (Stockholm: Royal Academy of the War Sciences).
} 
darbiavimo variklis buvo ekonominiai klausimai - kaip geriau išnaudoti mažèjančius gynybos biudžetus bendrai perkant bendrą techninę įrangą ir panašiai - ir buvo viešai pareikšta, kad šis formatas neturi tikslo kurti naujų karinio aljanso formų. ${ }^{11}$

2010 m., paskelbus dviejų „išminčių“, t. y. buvusio Latvijos ministro pirmininko ir užsienio reikalų ministro Valdžio Birkavo, atstovaujančio Baltijos šalis, ir buvusio Danijos gynybos ministro Søreno Gade, atstovaujančio Šiaurès šalis, ataskaitą buvo pasiektas labai svarbus ŠB8 bendradarbiavimo etapas. Ši ataskaita buvo išsami, bet pagrindinès jos rekomendacijos dèl bendradarbiavimo gynybos srityje išliko nepavojingoje politine prasme zonoje, būtent skatinti visas ŠB8 šalis prisidèti prie ES Šiaurès šalių kovinès grupès 2011 ir rekomenduoti Šiaurès šalims toliau stiprinti Baltijos gynybos koledžą Tartu, Estijoje. ${ }^{12}$ Baltijos gynybos koledžas yra jungtine Baltijos šalių gynybos akademija, finansiškai be kitų šalių išlaikoma ir Šiaurès šalių.

Tačiau, tai ko „išminčių“ ataskaita vis tik pasiekè, buvo strateginès sąvokos ŠB8 išviešinimas, kadangi ataskaitoje buvo pažymèta, kad „neatrodo, kad pagrindiniai dalyviai ir paprasti piliečiai turètų pakankamai žinių apie ŠB8 bendradarbiavimą "ir kad galima būtų daugiau padaryti viešosios diplomatijos prasme. ${ }^{13}$

Kad vyksta kažkas daugiau ŠB8 bendradarbiavimo gynybos srityje , tapo akivaizdu (jeigu ne viešosios nuomonès, tai bent jau ekspertų lygmenyje) 2011 m., kai Baltijos valstybès buvo pakviestos, tuomet pirmininkaujant Švedijai, prisijungti prie kai kurių NORDEFCO bendradarbiavimo sričių. ${ }^{14}$ Išplèstinis (ištęstinis) nuotolinis mokymasis, Šiaurès šalių lyčių lygybès operacijose centras ir veteranų reikalai, galbūt tuomet nebuvo pagrindiniai gynybos klausimai, bet parodè, kad ŠB8 integracija gynybos srityje pasiekẻ kitą lygmeni. Šis ịspūdis dar sustiprëjo 2012 m., kai Baltijos valstybès buvo pirmą kartą pakviestos dalyvauti NORDEFCO karinio koordinavimo komiteto susitikime. $^{15}$

Tačiau, jautrumo apraiškos tarp ŠB8 šalių išlieka, kai kalbama apie karinị solidarumą, t. y. abipusę pagalbą įranga. Visų pirma, tai susiję su tuo faktu, kad šešios iš aštuonių šalių jau yra NATO (pagrindinès politinio ir karinio solidarumo ir kolektyvinès gynybos Europoje organizacijos) narès ir né viena iš šių šalių nenori, kad ŠB8 bendradarbiavimas taptų NATO pakaitalu. Dar

\footnotetext{
${ }^{11}$ Žr. http://www.nordefco.org/facts-about-nordefco/.

12 Žr. http://baltikum2011.dk/fileadmin/templates/pdf/NB_8_WiseMen\%20Report.pdf, p. 11f.

${ }^{13}$ Ten pat, pp. $13 \mathrm{f}$.

${ }^{14} \mathrm{http}: / /$ www.nordefco.org/latest-updates/the-nordic/.

${ }^{15} \mathrm{http}: / /$ www.nordefco.org/latest-updates/the-baltic/.
} 
daugiau, Švedija ir Suomija, dvi buvusios neutralios ŠB8 šalys, yra vis dar veikiamos viešosios nuomonès savo elektorato, kuris atsilieka nuo realių Šiaurès ir Baltijos šalių bendradarbiavimo gynybos srityje ịvykių.

Jautrumo apraiškų pavyzdys yra taip vadinama 2011 m. Šiaurés šalių solidarumo deklaracija, kuri yra penkių Šiaurès šalių susitarimas, besiremiantis stipriomis bendromis jų vertybėmis ir noru bendradarbiauti, kovojant su iššūkiais „užsienio ir saugumo politikos srityse solidarumo dvasioje“. Šioje deklaracijoje buvo minimos „stichinès ir žmonių sukeltos nelaimès, kibernetinès ir teroristinès atakos". I akis krinta tai, kad karinè ataka, kaip solidarumo pagrindas, buvo neįtraukta ị deklaraciją. ${ }^{16}$

Kitas pavyzdys yra susijęs su NATO krizių valdymo pratybomis su teritorinès gynybos elementais „CMX 2011“, kurios buvo vykdomos vien kaip štabo mokymai, nors numatyti už Norvegijos krantų. Dalyvavo visos 28 NATO šalys, taip pat Suomija ir Švedija kaip šalys partnerès. Aktualu tai, kad, žvelgiant iš tradicinès Suomijos ir Švedijos perspektyvos, buvo visiškai pasinaudota NATO 4 ir 5 straipsnių konsultacijų ir operacijų mechanizmais.

Remiantis spaudos pranešimais, sumanytame scenarijuje Norvegija buvo karine prasme užpultoji šalis. Dẻl to Norvegija ir NATO papraše Švedijos karinès pagalbos. Labai trumpai apsvarsčiusi susijusius klausimus, Švedija ne tik dalyvavo kaip stebinti šalis partnerè, bet faktiškai suteikè svarias karines ir geopolitines priemones, siekdama padèti apginti, kartu su NATO, teritorini Norvegijos vientisumą nuo agresyvios Vinelando valstybès, išgalvotos salos valstybès ị vakarus nuo Norvegijos. ${ }^{17}$ Tai buvo atlikta tiksliai remiantis Švedijos 2009 m. solidarumo deklaracija, su kuria scenarijus, atrodo, visiškai derejo.

Tačiau, tikriausiai dèl su tuo susijusio politinio aktualumo, ne mažiausią vaidmeni čia suvaidino neigiamos viešosios nuomonès baimè - veiksmų, atliktų pratybų metu, Švedijoje viešai neaptarè nei vyriausybè, nei parlamentinė opozicija.

Pagaliau, atrodo, kad kai kurie klausimai, susiję su tuo, ką būtų galima pavadinti „saugumo politikos identitetu“, tapo svarbesni. Visų pirma, Baltijos valstybės taip pat yra linkusios pabrěžti savo ryšius su Šiaurès šalimis identiteto diskurso požiūriu. Šia prasme, Estijos atvejis yra pats lengviausias, kadangi estai etnine ir kalbos prasme yra artimai susiję su suomiais. Dar daugiau, ilga švedų valdymo Estijoje era (1561-1721) Estijos istoriniame diskurse žinoma

\footnotetext{
${ }^{16}$ Visą tekstą žr.: http://www.formin.fi/Public/default.aspx?contentid=217312.

${ }^{17}$ Žr. Claes Arvidsson (2012): "Sverige krigar ihop med Nato när Norge angrips" [Sweden Fights Together With NATO When Norway is Attacked", Svenska Dagbladet, sausio 15 d., http://www.svd.se/opinion/ledarsidan/sverige-krigar-ihop-med-nato-nar-norge-angrips_6770621.svd. Išsamiau apie pratybas taip pat žr. CMX 2011, http://uknato.fco.gov.uk/en/news/?view=News\&id=674946482.
} 
kaip „Auksinė Švedijos era“. Tačiau, taip pat derètų pastebèti, kad Lietuva Baltijos šalis, kuri, galbūt, yra mažiausiai susijusi su Skandinavijos valstybių kultūra, religija ir socialiniais klausimais - pastaraisiais metais ėmèsi ryžtingų pastangų persiorientuoti į Šiaurès šalis, bent jau strategiškai. ${ }^{18}$ Buvęs Lietuvos užsienio reikalų ministras, Audronius Ažubalis faktiškai ir oficialiai tai išdėstė taip:

Visai kaip Vazų valdymo laikotarpiu, užsienio politikos Šiaureje ir Rytuose yra tarpusavyje tiesiogiai susijusios, o svarbiausi politiniai Baltijos, Šiaurès ir Vidurio Europos šalių interesai sutampa. Atgijusi istorinė Šiaurès šalių partnerystė suteikia gerą progą Lietuvai netgi dar efektyviau skatinti demokratinius procesus ir kurti gerovę mūsų kaimynysteje esančiose Rytų Europos šalyse. ${ }^{19}$

Pratęsiant mintị, tai taip pat reikštų, kad Šiaurès ir Baltijos šalys turi svarbių saugumo problemų, kurios siejasi pakankamai glaudžiai. Tokiu būdu, šių šalių nacionalinis saugumas realiai negali būti svarstomas atskirai. Tai yra būdas apibrežti visą Šiaurès ir Baltijos šalių sritị, glaudžiai susijusią su tuo, ką britų tarptautinių ryšiu teoretikas, Barry'is Buzanas pavadino „saugumo kompleksu“" 20

Susiję, tačiau ne identiško pobūdžio vieši pareiškimai apie Švedijos saugumo politiką taip pat yra ịrodymas to, ką būtų galima pavadinti saugumo politikos identiteto pokyčiu. Pavyzdžiui, $2010 \mathrm{~m}$. pradžioje, kalbẻdamas svarbioje saugumo ir gynybos politikos konferencijoje, tuometis Švedijos gynybos ministras, Stenas Tolgforsas, teigè, kad dabar Švedijos gynybos politika prièmé „kaimynystès perspektyvą“:

Švedijos ginkluotụjų pajęgų struktūra ir orientacija turi ir išlaikys aiškų Baltijos jūros profili. [Švedijos] gynybos politika yra prièmusi naują kaimynystès perspektyvą, kurios pradinis taškas yra tai, kad Švedija kurs saugumą su kitais. (...) Saugumas yra kuriamas kartu su mūsų kaimynais Šiaurès šalyse ir su ES. Negalima matyti situacijos, kai grèsmè paveikia tik vieną iš mūsų regiono šalių. ${ }^{21}$

\footnotetext{
${ }^{18}$ Žr. "Lithuania’s strategic orientation towards the Nordic-Baltic region is based on historical experience, says Foreign Minister", Lithuania Tribune, 2011 m. spalio 19 d., ,http://www.lithuaniatribune. com/2011/10/19/lithuania \%E2\%80\%99s-strategic-orientation-towards-the-nordic-baltic-region-is-basedon-historical-experience-says-foreign-minister/.

${ }^{19}$ Ten pat. Vazų valdymo laikotarpis - taip pavadintas pagal tuometès Švedijos karališkosios šeimos dinastijos pavadinimą, kuri valde Švediją nuo 1523 iki $1654 \mathrm{~m}$. Buvo laikas, kai Švedija ir Lietuva turejo keletą labai painių sąsajų bendrus du karus ir karališkuosius asmenis, pvz., Žygimantas Vaza, kuris trumpą laiko tarpą buvo ne tik Švedijos, bet kartu ir Lenkijos karalius ir Lietuvos didysis kunigaikštis.

${ }^{20}$ Žr. Barry Buzan (1983): People, States and Fear: The National Security Problem in International Relations (Worcester: Wheatsheaf Books).

${ }^{21}$ Gynybos ministras Stenas Tolgforsas, (2010), Försvarsförmåga i fokus - ett försvarspolitiskt paradigmskifte [Defence Capability in Focus: A Defence Policy Paradigm Shift], kalba konferencijoje People and Defence, Sälen, Švedija, 2010 m . sausio 17 d., Mano vertimas. Žr. http://www.regeringen.se/sb/d/3214/a/138070.
} 
Panašiai teigè ir Užsienio reikalų ministras, Carlas Bildtas užsienio politikos 2012 m. deklaracijoje Švedijos parlamentui:

Švedijos saugumas kuriamas solidarizuojantis su kitais. Grèsmès taikai ir saugumui yra atremiamos kolektyviai ir bendradarbiaujant su kitomis šalimis ir organizacijomis. <...> Švedija neliks pasyvi, jei kita ES valstybè nare ar Šiaurès šalis patirs nelaimę ar bus užpulta. Mes tikimès, kad šios šalys pasielgs taip pat, jei panašiai nutiktų Švedijai. Mes turime būti pasirengę ir suteikti, ir priimti paramą, ir civilinę, ir karinę. <...> Bendradarbiavimas tarp Švedijos ir mūsų Šiaurès ir Baltijos kaimynių turi gilias šaknis. Kartu mes pasiekėme taikos ir laisvès visame mūsų regione, o šiandien mes galime sujungti mūsų pajėgas tam, kad šios mūsų vertybès sklistų už mūsų valstybių sienų. ${ }^{22}$

Akivaizdu, kad čia visiškai nebèra senojo izoliacionizmo, kuris beveik 200 metų buvo neatsiejama Švedijos saugumo politikos dalis.

\section{Tolesnès ŠB8 gynybos integracijos perspektyvos}

Kaip matome iš anksčiau pateiktos medžiagos, ŠB8 bendradarbiavimas yra besiplečianti sritis, apimanti ir gynybą. Be abejo, dabar ŠB8 šalys pripažista, - jei ir netiesiogiai - kad jos yra to paties saugumo komplekso dalis, t. y., kad svarbiausios jų nacionalinio saugumo problemos negali būti sprendžiamos nacionalineje izoliacijoje; jos visos priklauso nuo viena kitos saugumo. ${ }^{23}$ Todèl nenuostabu, kad keletas iš šių šalių, kaip buvo pažymèta anksčiau, formuluoja savo saugumo diskursą solidarumo rèmuose. Tačiau, tuo pat metu jautrumo apraiškos ir abejonės, susijusios su praktine karinio solidarumo išraiška, vis dar egzistuoja visose susijusiose šalyse. Viena priežasčių yra ŠB8 šalių sanglaudos nebuvimas narystės ES ir NATO požiūriu.

Tačiau tampa vis labiau aišku, kad pati ŠB8 koncepcija turi transformavimo galimybių. Tai aiškiai matyti Baltijos valstybių siekiuose sukti link Šiaurès regiono. Tai taip pat galima pamatyti vos ne revoliucinėje keleto pastaruju metų Švedijos saugumo ir gynybos politikos transformacijoje, kurią akivaizdžiai lėmė kaimyniško solidarumo koncepcija, nemažai susijusi su ŠB8 šalimis. Suomijoje šis procesas, gal kiek mažesniu mastu, taip pat matomas - Suomijos

\footnotetext{
${ }^{22}$ Užsienio reikalų ministras Carlas Bildtas, (2012): Statement of Government Policy in the Parliamentary Debate on Foreign Affairs, Trečiadienis, 15 vasario. Žr. http://www.regeringen.se/content/1/ c6/18/62/82/05a76 46d.pdf.

${ }^{23}$ Saugumo komplekso sąvoką, kaip paminèta anksčiau, pirmasis pavartojo Barry'is Buzanas (1983): People, States and Fear: The National Security Problem in International Relations (Worcester: Wheatsheaf Books). Ji neseniai buvo pritaikyta Baltijos jūros regionui: Mike Winnerstig (2012): Defence Integration in the Baltic Sea Security Complex - A Conceptual Approach, Kurt Volker ir Ieva Kupce (red.): NordicBaltic-American Cooperation: Shaping the US-European Agenda, (Washington, DC: SAIS/JHU - Center for Transatlantic Relations).
} 
saugumo ir gynybos politika yra veikiama didesnių pokyčių, bet atrodo, kad svarbiausia jų priežastis - ekonominiai veiksniai. ${ }^{24}$ Taip pat yra požymių, kad dar gilesne pačios politikos pagrindų transformacija vyks netolimoje ateityje. ${ }^{25}$ Nors, remiantis dabartine Suomijos doktrina, visiškai neaišku, ar Suomija paremtų bet kurią iš Baltijos valstybių, jei jos būtų užpultos išorinio veikèjo.

Vis dèlto, ši situacija lètai keičiasi, kaip buvo matyti iš anksčiau pateikto Švedijos atvejo. Pagrindinè formuojančių saugumo bendruomenę ŠB8 šalių vidutinès trukmès ir ilgalaike ateities problema yra ir išliks ŠB8 šalių didžiųjų strategijų harmonizavimas, t. y. saugumo politikos orientacija. Praktiškai tai reiškia bendrą jų narystę tame pačiame NATO gynybos aljanse. Bendros narystès stoka tampa vis labiau problemiška ŠB8 bendradarbiavime gynybos srityje ir tai girdèti daugelio aukštu politinių lyderių kalbose Baltijos valstybėse ir yra susiję su praktinėmis problemomis, iškylančiomis NORDEFCO kontekste, ypač kalbant apie Švedijos ir Norvegijos bendradarbiavimą gynybos srityje. ${ }^{26}$

Žvelgiant iš saugumo politikos perspektyvos, svarbiausia problema yra Švedijos ir Suomijos ịstojimas ị NATO. Todèl šią problemą derètų panagrinèti išsamiau.

\section{Narystès NATO debatai Suomijoje ir Švedijoje}

Ir Švedijoje, ir Suomijoje, dèl tradicinių vidaus politinių priežasčių buvo juntamas nenoras prisijungti prie NATO, nepaisant to, kad šis aljansas yra akivaizdi politinio ir karinio solidarumo visoje transatlantinèje erdveje išraiška. Šis nenoras iš esmès trukdo ŠB8 praktiškai suformuoti tikrą saugumo bendruomenę. Jeigu visų aštuonių valstybių gynybos planavimas būtų vykdomas koaliciniuose NATO rèmuose, beveik visa Baltijos jūros zona atsidurtų vienoje politinëje ir karinejje struktūroje, kas ne tik dar glaudžiau sutelktų visas ŠB8 šalis, bet ir žymiai sumažintų visas karinių grėsmių pavojų regionui formas. Bet kurio agresoriaus manevro laisvè tiesiog būtų nepaprastai apribota.

\footnotetext{
${ }^{24}$ Žr. pvz., Bo Ljung and Karlis Neretnieks (2011), Kommande reformering av den finländska försvarsmakten [The Future Reforms of the Finnish Armed Forces], FOI Memo 3843 (Stockholm: FOI).

${ }^{25}$ Žr. pvz., Ari Puheloinen (2013): Speech by the Commander of the Finnish Armed Forces at the inauguration of the 206th Defence Course, Helsinki, Finland, rugsejo 23 d. (http://www.puolustusvoimat.fi/portal/ puolustusvoimat.fi).

${ }^{26}$ Žr. pvz., Artis Pabriks (2013): I väntan på svenskt medlemskap i Nato [Waiting for Swedish NATO membership], Frivärld Magasin, http://www.frivarld.se/magasin/i-vantan-pa-svenskt-medlemskap-i-nato/). Tuo metu Pabrikas buvo Latvijos gynybos ministras. Apie Švedijos ir Norvegijos problemas, žr. pvz.Norge bryter svenskt vapenkontrakt [Norway breaks Swedish arms deal], Swedish Radio, 2013 m. gruodžio 6 d. http://sverigesradio.se/sida/artikel.aspx?programid=83\&artikel=5726468.
} 


\subsection{Suomijos atvejis}

Ilgą laiką Suomijos gynybos doktrina rèmèsi trimis pagrindiniais ramsčiais: teritorine visos šalies gynyba, neprisijungimu ir karo tarnybos prievole. Beveik 70 \% Suomijos gyventojų ryžtingai palaiko šitokią struktūrą, taip pat ir šaukimo ị karo tarnybą sistemą, kuri laikoma nacionaline vertybe ne tik karine, bet ir visuomenès sanglaudos ir piliečių lojalumo prasme ${ }^{27}$.

Suomijos ginkluotųjų pajègų struktūros pagrindą sudaro šešios modernios ịvairių rūšių armijos brigados, nedidelès, tačiau modernios oro pajègos (kurių pagrindas yra F-18 Hornet sistema), nedidelis ir šiek tiek ribotas laivynas, ir, pagaliau, daug nemodernizuotų pajegų, skirtų teritorinei gynybai, turinčių rimtų trūkumų technikos ir pasirengimo atžvilgiu. Bendros Suomijos ginkluotosios pajègos po mobilizacijos būtų daugiau kaip 230000 karių. Šis skaičius mažesnis negu prieš keletą metų (maždaug 320000 karių). Vis dèlto, dèl Europos finansinès krizès ir euro zonos problemų Suomija atsidūrè labai sunkioje padètyje. Dèl šios priežasties planuojama mažinti ir taupyti gynybos biudžetą vidutiniškai 15-20 \%. Taip pat planuojamas daugelio brangiai kainuojančių programų, tokių kaip F-18 sistema, modernizavimas ir senosios sovietų laikų kariuomenès technikos kapitalinis remontas. ${ }^{28}$

Suomijoje diskusijos apie gynybą pirmiausia siejamos su ekonominèmis, bet ne su karinèmis ar geopolitinèmis aplinkybėmis. Ekonominė krizè ir ryškus izoliacionistinès „Tikrųjų suomių“ partijos pakilimas per visuotinius rinkimus 2011 metų, kai ši partija gavo daugiau nei 19 \% balsų, privertè debatuose dèl Suomijos gynybos daugiau dèmesio skirti tradicinès teritorinès gynybos pozicijai, o ne tarptautinèms operacijoms užsienyje. ${ }^{29}$

Diskusijose dèl ekonominių problemų ir akivaizdžių ǐšūkių, kylančiu Suomijos ginkluotosioms pajegoms ir Suomijos saugumo politikos doktrinai, šiais klausimais buvo rastas galimas sprendimas - Suomijos narystė NATO. Tačiau labai neịprastas ar bent jau gana sudètingas Suomijos debatų pobūdis yra toks todèl, kad ilgą laiką i galimą narystę NATO buvo žiūrima kaip ì ginčytiną klausimą, daugiausia dèl vieningos visuomenès nuomonès prieš šią idèją ir dèl to, kad viena po kitos buvusios vyriausybès skelbė, kad jų kadencijos

\footnotetext{
${ }^{27}$ Apie tokią diskusiją žr. pvz. Bo Ljung and Karlis Neretnieks (2011), Kommande reformering av den finländska försvarsmakten [The Future Reforms of the Finnish Armed Forces], FOI Memo 3843 (Stockholm: FOI).

${ }^{28}$ Žr. pvz. Bruce Jones (2011): "Finnish military chief braces for deeper cutbacks", Jane’s Defence Weekly, rugsèjo $14 \mathrm{~d}$.

${ }^{29}$ Johanna Minkkinen (2011): "Nu kritiseras operationer i utlandet" ["Now International Operations are Critiziced”], Hufvudstadsbladet, spalio $12 \mathrm{~d}$.
} 
metu šio tikslo nebus siekiama. Tuo pat metu Suomijos pareigūnai atliko dvi ar tris oficialias analizes, siekdami nustatyti, kokias pasekmes sukeltų narystė NATO, o Suomijos oficialiojoje doktrinoje ilgą laiką buvo ịsitvirtinęs vadinamasis „NATO pasirinkimas“, t. y. galimybè, esant reikalui, prisijungti prie Aljanso. ${ }^{30}$ Tačiau daugelis įvykių, susijusių su Šiaurès šalių bendradarbiavimu gynybos srityje per pastaruosius keletą metų parodè, kokios vis dar aktualios yra gynybos problemos Suomijoje, kadangi neprisijungimas ten tebèra rimtai vertinamas dalykas, turintis prasmę ir atitinkamas pasekmes. Pavyzdžiui, 2013 metais Suomijai pradejus diskusijas dèl dalyvavimo NATO oro policijos misijoje virš Islandijos kartu su Švedija, visuose Suomijos politikos sluoksniuose kilo ilgi ir labai karšti debatai. Keletas aukštų Suomijos parlamentarų, tarp jų ir iš valdančiosios koalicijos partijų, dèl to išreiškẻ rimtą susirūpinimą, remdamiesi tuo, kad Islandija yra NATO valstybe ir kad neprisijungusiai Suomijai nèra reikalo dalyvauti NATO šalies oro erdvès stebejjime. Nepaisant to, kad iš NATO oro policijos Islandijos misija buvo pakeista ị paprasčiausias oro erdvès stebejjimo pratybas, trumpai tariant, kone pusẻ Suomijos gyventojų kartu su keliomis partijomis parlamente griežtai pasisake prieš Suomijos dalyvavimą šiose pratybose apskritai. Vis dèlto, Suomijos parlamentas galiausiai nusprendè, kad Suomijos oro pajègos turètų dalyvauti. ${ }^{31}$

Žiūrint iš Šiaurès ir Baltijos šalių perspektyvos, šie debatai ir jų tolesne raida kelia didelį susidomejimą, kadangi atrodo, kad Suomijos plačioji visuomenè tiki, kad Šiaurès šalių bendradarbiavimas gynybos srityje yra vertingas dalykas; 2013 m. apklausos metu net 93\% respondentų pareiškè, kad Šiaurès šalių bendradarbiavimas gynybos srityje yra vertingas arba labai vertingas žingsnis (o apie $71 \%$ buvo laikèsi nuomonès, kad Suomijos narystė NATO nèra geras sumanymas). ${ }^{32}$ Galima daryti išvadą, kad Suomijos plačiosios visuomenès požiūriu, Šiaurès šalių gynyba yra geras dalykas tol, kol joje nedalyvauja NATO šalys. Tačiau tai palieka tris penktadalius Šiaurès valstybių už Šiaurès šalių gynybos struktūros ribų.

Autoritetingiausiai apie NATO narystès problemą kalbėjo Suomijos užsienio reikalų ministras Erkki Tuomioja savo kalboje 2013 m. rugsèjo mèn. Tuomioja - socialdemokratas - be kita ko, pareiškè, kad narystė NATO, ypač

\footnotetext{
${ }^{30}$ Yrsa Grüne (2011), "Varför tala om icke-frågan NATO?" ["Why talk about the NATO Membership NonIssue"], Hufvudstadsbladet, lapkričio $1 \mathrm{~d}$.

${ }^{31}$ Žr. pvz. Heidi Hakala (2013), "Finland berett bidra till att övervaka Islands luftrum" ["Finland prepared to contribute to surveillance of Icelandic airspace"], spalio $30 \mathrm{~d}$., http://www.arbetarbladet.fi/nyheter/allanyheter/8474-finl-nd-red-tt-verv

${ }^{32}$ Žr. Finnish Ministry of Defence (2013): Finns' opinions on Foreign and Security policy, Defence and Security issues 2013, http://www.defmin.fi/files/2672/report_text_in_english.pdf.
} 
NATO sutarties 5-ojo straipsnio gynybos garantijos, toli gražu nesustiprins Suomijos saugumo, ir tokios nuomonés bus laikomasi ne tik dabartinès vyriausybės kadencijos metu, bet taip pat ir po kitų rinkimų. ${ }^{33}$ Savaime suprantama, kad tai buvo nepaprastai stiprus pareiškimas. Naryste Aljanse, kurio pagrindas yra bendros gynybos garantijos ir kuris jungia 28 šalis ir apie 800 milijonų žmonių, kurie kartu reiškia 50 \% nuo BVP ir daugiau nei 50 \% pasaulio karinių gynybos išlaidų ir pajegumų, Tuomiojos nuomone, jokiu būdu negalès sustiprinti Suomijos saugumo.

Suomijai, kaip ir daugeliui kitų Šiaurès ir Baltijos valstybių, didžiausia kliūtis yra Rusija. Kai kuriems, kaip, pavyzdžiui, Suomijos nacionalinio gynybos koledžo vyresniųjų tyrëjų grupei, Rusija reiškia potencialią, rimtą grèsmę Suomijos suverenitetui ir teritoriniam vientisumui. ${ }^{34} \mathrm{Kitiems,} \mathrm{kaip,} \mathrm{pavyzdžiui,}$ tuo metu (2012 m.) buvusiam Suomijos karinès žvalgybos vadovui admirolui Georgijui Alafuzoffui, neatrodè, kad Rusija keltų kokią nors karinę grèsmę Suomijai. Visiškai priešingai, pasak Alafuzoffo, Suomijos narystė NATO galètų kelti rūpesčių Suomijai ekonominiu požiūriu, kadangi tuomet ịprasti, neantagonistiški Suomijos ir Rusijos santykiai galètų virsti labiau priešiškais. ${ }^{35}$ Ši versija yra viena iš trijų svarbiausių argumentų, vyraujančių Suomijos viešojoje nuomoneje, kodèl Suomija neturètų stoti ị NATO. Tačiau atrodo, kad svarbiausia aplinkybė, kuria remiasi $71 \%$ gyventojų, nusiteikusių prieš narystę NATO, yra ne Rusijos veiksnys, bet ịspūdis, kad Suomijos kariuomenè, kaip dalis NATO mechanizmo, bus priversta kariauti tolimose vietovese dèl NATO didžiųjų valstybių, o ne dèl Suomijos interesų. ${ }^{36}$

Tačiau keletą kartų oficialūs Rusijos asmenys ir netiesiogiai, ir atvirai i̊spejjo Suomiją, kad jei prisijungus prie NATO, pasekmès gali būti rimtos, nes Rusija pasisako prieš bet kokią Vakarų aljanso plètrą. 2012 m. per vizitą Helsinkyje Nikolajus Makarovas, tuometis Rusijos ginkluotụjų pajègų vadas, labai tiesiai pareiškė, kad Suomijos narystė NATO Maskvoje bus faktiškai laikoma grèsme Rusijos saugumui. Generolas Makarovas netgi pabrèžè, kad jau pats Šiaurès šalių bendradarbiavimas gynybos srityje yra saugumo problema $\mathrm{Ru}-$

\footnotetext{
${ }^{33}$ Žr. Erkki Tuomioja (2013): Speech by the Minister for Foreign Affairs of Finland, Erkki Tuomioja, to the Paasikivi Society, Helsinki, rugsèjo 4 d. http://www.formin.fi/public/default.aspx? contentid=282965\&nodei $\mathrm{d}=15145$ \& contentlan $=2$ \& culture $=$ en-US.

${ }^{34}$ Žr. pvz. Markus Lindqvist (2011): "Ryssland kan inta Norden och Baltikum när som helst" [Russia can invade and occupy the Nordic-Baltic countries anytime] Hufvudstadsbladet, rugsejjo $21 \mathrm{~d}$.

${ }^{35}$ Olli Ainola (2012): "På randen till en ny revolution: Intervju med Försvarsmaktens underrättelsechef Georgij Alafuzoff" ["At the Verge of a New Revolution: Interview with the Head of Military Intelligence of the Finnish Armed Forces Georgij Alafuzoff”], Talouselämä, sausio $5 \mathrm{~d}$.

${ }^{36}$ Žr. Finnish Ministry of Defence (2013): Finns' opinions on Foreign and Security policy, Defence and Security issues 2013, http://www.defmin.fi/files/2672/report_text_in_english.pdf, p.8.
} 
sijai. ${ }^{37}$ Visgi, neatrodo, kad ši, tam tikra prasme agresyvi, pozicija, kurią kritikavo Suomijos oficialūs asmenys, ${ }^{38}$ lèmé Suomijos visuomenès mažiau priešišką nuomonę narystès NATO atžvilgiu. Tas pat pasakytina ir apie Makarovo ispejjimus, kuriuos pakartojo Rusijos gynybos ministras Sergejus Šoigu vizito Helsinkyje 2013 m. vasarą metu. ${ }^{39}$ Rusijos karo ekspertas pulkininkas Viktoras Baranecas ịspejjo, kad Suomijai ir Švedijai ịstojus ị NATO, šios šalys taptų „potencialiais taikiniais Rusijos bombonešiams, povandeniniams laivams ir strateginems raketoms s. ${ }^{40}$

Taigi, kol kas perspektyviausi Šiaurès šalių bendradarbiavimo gynybos srityje aspektai tiek Suomijos vyriausybès, tiek Suomijos viešosios nuomonès požiūriu yra dvišaliai Suomijos ir Švedijos ryšiai. Kartais šie ryšiai taip stipriai akcentuojami, kad kai kurie veikẻjai žiūri ị juos, kaip ị dvišali gynybos aljansą, tačiau šị požiūrị labai greit nuslopina aukšti Suomijos pareigūnai; Šiaurès šalių bendradarbiavimas gynybos srityje apskritai ir Suomijos, ir Švedijos santykiai gynybos srityje nẻra gynybos aljanso kūrimas, o tik lèšų taupymo būdas, o bendradarbiavimas daugeliu karinių klausimų, kai tai įmanoma, dar nereiškia diskusijų dèl tarpusavio gynybos garantijų ar kažko panašaus. Suomių požiūriu, Suomija (ir tik Suomija) ginasi karine prasme. ${ }^{41}$

2013 m. rugpjūčio mèn. kalbėdamas apie Suomijos saugumo politikos ateitị, Suomijos prezidentas Sauli Niinistö padare ịdomų pareiškimą. Savo kalboje, skirtoje visiems Suomijos ambasadoriams, dalyvaujantiems kasmečiame susirinkime, Niinistö pakomentavo Suomijos saugumo politikos (ypač susijusios su NATO klausimu) kaip panašios ị „laikymąsi nuošaleje“ kritiką, sakydamas, kad „taip jau yra, bet man atrodo, kad tai gana gera vieta“42. Kai kurie analitikai suskubo kritikuoti ši pareiškimą. Tarp jų buvo ir daugelis aukštų, dažnai atsistatydinusių Suomijos pareigūnų, kurie palaikẻ Suomijos stojimą

\footnotetext{
${ }^{37}$ Žr. " Russian general warns Finland about NATO", Helsingin Sanomat, 2012 m. birželio 6 d., http://www. hs.fi/english/article/Russian+general+warns+Finland+about+NATO/1329104270495.

${ }^{38} \check{Z}$ r. Finland wants clarification of Russian general's comments, Helsingin Sanomat, 2012 m. liepos

7 d. http://www.hs.fi/english/article/Finland+wants+clarification+of+Russian+general's+commen ts/1329104275605.

${ }^{39}$ Peter Buchert (2013): "Sjojgu tog fram tung rysk vokabulär [Sjojgu used the heavy Russian vocabulary]", Hufvudstadsbladet, gegužès $30 \mathrm{~d}$.

${ }^{40}$ Matts Lindqvist (2013): "Rysk expert varnar för Nato-anslutning [Russian expert warns against NATO accession"], Hufvudstadsbladet, birželio $26 \mathrm{~d}$.

${ }^{41}$ Žr. pvz. Matts Lindqvist (2013): "Sverige och Finland ense - ingen allians [Sweden and Finland agree no alliance]", Hufvudstadsbladet, sausio 18 d., and Mika Peltonen (2013): "Nordefco ingen försvarsallians [Nordefco not a defence alliance]", Hufvudstadsbladet, vasario $13 \mathrm{~d}$.

${ }^{42}$ Žr. Sauli Niinistö (2013): President of the Republic Sauli Niinistö's speech at the Annual Ambassadors' Meeting, Finlandia Hall, Helsinki, rugpjūčio 27 d., http://www.tpk.fi/public/default.aspx?contentid= 282762\&nodeid $=44810$ \& contentlan $=2 \&$ culture $=$ en-US.
} 
i NATO. ${ }^{43}$ Tačiau faktiškai atrodo, kad ši neutralumo politika yra giliai įsišaknijusi Suomijos saugumo politikoje, ir greičiausiai išliks joje dar ilgą laiką. Tai galbūt galètų pakisti, jei Suomijos vakarinès kaimynès Švedijos politikoje ịvyktų esminių pokyčių.

\section{2. Švedijos atvejis}

Daugelį metų (tiksliau, iki 2013 m.) narystès NATO reikalas buvo gana sunkus klausimas diskusijoje dèl Švedijos gynybos ir saugumo. Nors ginčai dèl narystės Švedijos gynybos struktūrose visą laiką egzistavo nuo maždaug 1997 m., dauguma visuomenès nuomonès apklausų nuo Šaltojo karo pabaigos iki 2012 m. parodé, kad apie pusė gyventojų buvo prieš narystę Aljanse, o apie $25 \%$ pasisakè už narystę. ${ }^{44}$ Tai reišké, kad tik ideologiškai motyvuotos mažosios partijos parlamente (iš esmès tik liberalų partija) apskritai kèlè ṣ̌ klausimą. Likusioms parlamentinėms partijoms šis klausimas buvo arba suvokto nacionalinio identiteto reikalas (turint galvoje, kad būti švedu reiškia būti neprisijungusiam ir neutraliam, o NATO narystės idejja yra beveik atgrasi), arba kažkas, kas teoriškai buvo pageidautina, tačiau praktiškai už tai neverta kovoti (taip yra su vadovaujančia Moderatų centro dešiniųjų partija, kuri vadovauja vyriausybei nuo 2006 m. . $^{45}$

Tačiau 2013 m. situacija pasikeitè. Pirmiausia, pasigirdo atgarsiai dèl dramatiškos ir fundamentalios gynybos reformos, kurios pradžia buvo anksčiau minètas $2009 \mathrm{~m}$. gynybos įstatymas; gynybinès pajègos turèjo būti stiprinamos, pradedant nuo 2005 m. situacijos, tačiau tik iki 50000 bendro kariu skaičiaus. Šio gynybos ịstatymo pagrindas buvo tai, kad Švedijos ginkluotosios pajègos turi būti pasirengusios ir pajėgios „čia ir dabar“. Tai reiškè, kad karo prievolès nebelieka, o būsimąsias pajègas sudaro profesionalūs kareiviai, karininkai ir kontraktą pasirašę rezervistai. ${ }^{46}$

\footnotetext{
${ }^{43}$ Žr. pvz. Pauli Järvenpää (2013): Sitting on the fence (International Center for Defence Studies, Tallinn, Estonia), http://www.icds.ee/index.php?id=73\&cHash=5ala2c5eba\&tx_ttnews\%5Btt_news\%5D=1381, and Henrik Helenius (2014): "Fd Moskva-ambassadören Markus Lyra: Finland bör gå med i Nato [Exambassador to Moscow Markus Lyra: Finland should join NATO], Arbetarbladet, sausio 30 d., http://www. arbetarbladet.fi /nyheter/alla-nyheter/18395-fd-m-skv-m-ss-d-ren-m-rkus-lyr-finl-nd-b-r-g-med-i-n-t. ${ }^{44}$ Žr. pvz. Mike Winnerstig (1997): Alliansfrihet eller NATO-medlemskap? Sweden's and Europe's security after NATO's enlargement (Stockholm: Swedish Institute of International Affairs) for one of the earliest examples of a more in-depth discussion on Sweden and NATO.

${ }^{45}$ Žr. Joakim Berndtsson, Ulf Bjereld \& Karl Ydén (2012): "Svagt stöd för Nato-anslutning" ["Weak support for NATO accession"], Svenska Dagbladet, gegužès 26 d., http://www.svd.se/opinion/brannpunkt/ svagt-stod-for-nato-anslutning_7231251.svd.

${ }^{46} \check{Z}$ r. Ministry of Defence (2009), A Useful Defence, The Swedish Government's Bill 2008/09:140,. http:// www.regeringen.se/content/1/c6/12/29/57/853ca644.pdf.
} 
Ši ginkluotųjų pajègų struktūra buvo žymiai didesnè ir efektyvesnè nei buvusi 2005 m., kai ginkluotųjų pajègų vaidmuo buvo iš esmès neaiškus, o daugumai karinių dalinių reikejjo vienerių metų ar ilgesnio apmokymo, kad jie galètų pradèti operatyvinę veiklą. Tačiau žmonès - tiek valstybès aparate, tiek gyventojai apskritai - vis dar lygino ją su $1980 \mathrm{~m}$. Švedijos ginkluotosiomis pajègomis, kai karo prievolès sistema leido Švedijai - tada turejjusiai apie $9 \mathrm{mln}$. gyventojų šaliai - mobilizuoti maždaug 800000 karių, arba daugiau kaip pusę Jungtinių Amerikos Valstijų (šalies su maždaug 330 $\mathrm{mln}$. gyventojų ir vienintelès pasaulio supervalstybės) dabartinès reguliariosios kariuomenès. Be to, Švedijoje bendras požiūris ị Švedijos ginkluotụjų pajègų vaidmenị buvo iš esmès paveldètas iš Šaltojo karo laikų; tik Švedijos ginkluotosios pajègos gina Švediją - niekas daugiau - ir jos gina visą šalị visą laiką.

Taigi, galima manyti, kad 2012 m. pavasari pasklidusi žinia apie labai aiškią Švedijos karinę paramą Norvegijai per anksčiau minètas NATO imitacines pratybas $C M X 11$, būtų sukèlusi diskusijų. Pratybų metu beveik visos Švedijos karinès oro pajègos buvo paskirtos Norvegijos teritorijos gynybai, neskaitant sprendimo (kariniame žaidime) leisti NATO naudotis Švedijos oro erdve ir teritorija NATO nuožiūra. ${ }^{47}$ Vargu, ar tai yra toks elgesys, kurio tikimasi iš neutralios šalies, tačiau tai buvo visiškai logiškas sprendimas pagal taip pat anksčiau minètą $2009 \mathrm{~m}$. Solidarumo deklaraciją. Tai visiškai nesukèle jokių debatų Švedijos visuomenèje.

Netgi generolo Makarovo kalba 2012 m vasarą Helsinkyje (taip pat minèta anksčiau) nesukèle diskusijų, nors kai kuriuose straipsnių komentaruose buvo daroma išvada, kad toks požiūris kartu su vykstančiu Rusijos persiginklavimu turètų paspartinti Švedijos prisijungimą prie NATO. ${ }^{48}$ Jokių didesnių visuomenès diskusijų nesukèlè ir po to sekęs atsistatydinančio Švedijos karinès žvalgybos vadovo majoro Stefano Kristianssono komentaras, kad Rusijos persiginklavimas yra problema, ị kurią Švedija turi žiūrèti rimtai. ${ }^{49}$

Tačiau diskusijos prasidejo nuo Švedijos vyriausiojo ginkluotųjų pajègų vado generolo Sverkero Göransono (iš esmès, Švedijos gynybos vadovo) interviu, kuris buvo paskelbtas $2013 \mathrm{~m}$. pradžioje. Pasak generolo Göransono, Švedijos dalyvavimas kariniuose imitaciniuose žaidimuose $2012 \mathrm{~m}$. rudeni atskleidè, kad būsimoji Švedijos ginkluotųjų pajègų struktūra (reformavus gy-

\footnotetext{
${ }^{47}$ Mikael Holmström (2012): "Sverige redo kriga för Nato [Sweden prepared to go to war on behalf of NATO]”, Svenska Dagbladet, birželio $21 \mathrm{~d}$.

${ }^{48}$ Dagens Nyheter (2012): "Risken med ett öppet förhållande [The risks of a free relationship]" redakcijos straipsnis, liepos $22 \mathrm{~d}$.

${ }^{49}$ Mikael Holmström (2012): "MUST ser ökat hot österifrån [Swedish Military Intelligence Sees Increased Threat from the East]", Svenska Dagbladet, rugsèjo 27 d.].
} 
nybą iki 2019 m. ar panašiai) bus pajègi apie savaitę ginti Švediją nuo ribotos atakos. $^{50}$

Jei Švedija būtų NATO narè, šis faktas nebūtų buvęs laikomas labai nesuprantamu ar kontraversišku dalyku. Dauguma NATO šalių, kurios savo dydžiu yra lygios Švedijai, turi panašaus pajègumo gynybines pajègas ir norèdamos apsiginti, pasikliauja pastiprinimu iš kitų sajungininkių. Tačiau Švedijoje, kur visuomenè mano, kad Švedijos ginkluotosios pajègos pačios, be jokios pagalbos, turi sugebėti apginti visą šalì, šis gynybos vadovo pareiškimas buvo tikra politinè bomba. Daugybė politikų, komentatorių, parlamento narių, žurnalistų ir plačiosios visuomenès narių reiškè nuostabą, susijusią su Švedijos ginkluotụjų pajègų ateitimi. ${ }^{51}$

Kitame interviu generolas Göransonas toliau pareiške, kad užuot planavus visos šalies gynybą, būsimų ginkluotųjų pajègų apribojimai reiškia, kad karinės gynybos planavimas realiai galimas tik penkioms svarbiausioms šalies zonoms - ir tik vieną iš jų ịmanoma ginti nuolat. Švedijos debatuose tai atrodẻ beveik taip pat dramatiškai, kaip ir gynybos vadovo pareiškimas. Tai greitai buvo pavadinta „vienos savaitės gynyba“. Tačiau tuo drama nesibaigè. Generolas Göransonas pasièmè kelias laisvas savaites dèl ligos, o teisèsaugos organai pradejo tyrimą, dèl karinių paslapčių atskleidimo. ${ }^{52}$ Diskusijos dèl gynybos darèsi vis karštesnès, nors kaltinimai Göransonui buvo panaikinti.

2013 m. sausio mèn., svarbioje Švedijos saugumo politikos konferencijoje NATO Generalinis sekretorius Rasmussenas, taip pat skandinavas ir buvęs Danijos ministras pirmininkas, labai aiškiai pasakè, kad NATO nèra įsipareigojusi padèti ne NATO narès. Tai iš dalies buvo atsakymas ị klausimą ar Švedija gali pasikliauti kitų šalių karine pagalba, remdamasi 2009 m. Švedijos vienašale solidarumo deklaracija. ${ }^{53}$ Praẻjus porai savaičių, duodamas interviu Švedijos visuomeniniam radijui, tuometis Norvegijos gynybos ministras pasakè tą patị ir pridūrè, kad Norvegija visiškai neturi jokios kariuomenès, kuri būtų pasirengusi ginti ką nors, išskyrus Norvegijos teritoriją kartu su NATO sajungininkemis. ${ }^{54}$

Be to, Rusijos karinès pratybos, tiesiogiai nukreiptos prieš Švediją, tapo

\footnotetext{
${ }^{50}$ Mikael Holmström (2013): “Försvar med tidsgräns [A Defence with a Time Limit]”, Svenska Dagbladet, sausio $2 \mathrm{~d}$.

${ }^{51}$ Ewa Stenberg (2012): "Uttalandet från ÖB är en politisk bomb [The CHOD statement a political bomb]", Dagens Nyheter, sausio $3 \mathrm{~d}$.

${ }^{52}$ Mikael Holmström (2013): "Försvarsplan bara för fem områden [Defence plans only for five areas]", Svenska Dagbladet, sausio 26 d.

${ }^{53}$ Mikael Holmström (2013): "NATO lovar inget ingripande [NATO does not promise any assistance]", Svenska Dagbladet, sausio $15 \mathrm{~d}$.

${ }^{54}$ Z̆r. interviu su Anne-Grete Strøm-Erichsen, Norvegijos gynybos ministre, 2013 m. sausio 24 d., http:// sverigesradio.se/sida/artikel.aspx?programid=83\&artikel $=5453467$.
} 
neatskiriama dalimi diskusijų apie gynybą Švedijoje. Pirmiausia, naikintuvų ir bombonešių formuotè pasuko link Švedijos objektų 2013 m. Didžiojo penktadienio naktị. Kadangi tai viena iš didžiausių švenčių Švedijoje, visi pilotai, galintys perimti priešo orlaivius, turëjo laisvadienius, todèl jokie švedų orlaiviai nepakilo prieš rusų lèktuvus (kurie, visgi, neịskrido ị Švedijos teritoriją). Tačiau Danijos F-16 iš NATO oro policijos misijos Šiauliuose pakilo i orą, pasirodžius Rusijos orlaiviams. Tai dar labiau sumenkino Švedijos karines oro pajègas. ${ }^{55}$ Vèliau tais pačiais metais, rusų žvalgybinis laivas praplaukẻ tarp Gotlando salos ir Švedijos žemyninès dalies, vykdydamas ryšių žvalgybos užduotis, susijusias su tuo pačiu metu Švedijoje vykusiomis svarbiomis tarptautinèmis karinėmis pratybomis. ${ }^{56}$ Netrukus po šio incidento, „Zapad 2013“ pratybų metu, Rusijos karinių oro pajėgų daliniai surengè dar vieną imitacinę oro ataką, nukreiptą $\mathfrak{i}$ taikinius Švedijoje. ${ }^{57}$

Visa tai, matyt, turejo gilų ir ilgalaiki poveikị tiek parlamentarų, tiek visuomenès nuomonei. Tradiciškai, tik dvi iš keturių dabartinès Švedijos vyriausybès koalicijos partijų (tarp jų ministro pirmininko, užsienio reikalų ministro ir gynybos ministro Moderatų liberalų-konservatorių partija) atvirai propaguoja Švedijos narystę NATO. Kitos dvi partijos, Centro (agrarinè) ir Krikščionių demokratų, tradiciškai visada stipriai rèmé Švedijos neprisijungimą prie NATO, bet dabar yra oficialiai neapsisprendusios ir reikalauja sudaryti parlamentinį tyrimo komitetą, kuris išnagrinètų Švedijos narystès NATO argumentus už ir prieš. Pastarasis reikalavimas buvo iš dalies igyvendintas, nes Švedijos vyriausybė neseniai paskyrè vyresnijji, atsistatydinusị ambasadorių, kuris turejo sudaryti komitetą, nagrinejjantị Švedijos karinị bendradarbiavimą su Šiaurès šalimis, ES ir NATO. ${ }^{58}$ Ši žingsnị tuoj pat sukritikavo socialdemokratu spauda, kadangi socialdemokratai (kartu su likusia opozicijos dalimi, t. y. žaliaisiais, buvusia komunistų partija ir dešiniojo sparno populistine Švedijos demokratų partija) visais būdais priešinasi narystei NATO. ${ }^{59}$

Pasikeitusi situacija Švedijos parlamente atsispindejo visuomenès nuomonèje apie narystę NATO. Pagal visuomenès nuomonès apklausą gegužès mèn.

\footnotetext{
${ }^{55}$ Mikael Holmström (2013): "Ryskt flyg övade anfall mot Sverige [Russian Aircraft Exercised Attacking Sweden], Svenska Dagbladet, balandžio $24 \mathrm{~d}$.

${ }^{56}$ Mikael Holmström (2012): "Här spionerar Ryssland på Sverige [Here, Russia is spying against Sweden]", Svenska Dagbladet, rugsèjo $21 \mathrm{~d}$.

${ }^{57}$ Olle Lönnaeus (2013): "Het militärhöst runt Östersjön [Hot military autumn around the Baltic Sea]", Sydsvenskan, lapkričio 9 d., http://www.sydsvenskan.se/sverige/het-militarhost-runt-ostersjon/.

${ }^{58}$ Gynybos ministerija (2013): Översyn över internationella samarbeten [Overhaul of international cooperative ventures]", gruodžio 28 d., http://www.regeringen.se/sb/d/17014/a/231323.

${ }^{59}$ Žr. pvz. Anders Lindberg (2014): "Vilket problem är Nato lösning på? [Which problem is NATO a solution to?", sausio 11 d., http://www.aftonbladet.se/ledare/ledarkronika/anderslindberg/article 18158319.ab.
} 
$32 \%$ švedų pasisake už Švedijos narystę NATO (palyginti su $23 \% 2012$ m. ), o $40 \%$ buvo prieš (palyginti su $40 \% 2012 \mathrm{~m}$.), o likusieji buvo neapsisprendę. Ši apklausa buvo ypač ịdomi tuo, kad atskleidè, kad apie $24 \%$ visų socialdemokratų ir dauguma (56 \%), Švedijos demokratų pasisakè už Švedijos narystę NATO. Kitoje apklausoje, kuri buvo atlikta vykdant Vokietijos Maršalo fondo Transatlantinių tendencijų projektą, $36 \%$ buvo už narystę NATO (palyginti su $24 \% 2012$ m.), o $56 \%$ buvo prieš. ${ }^{60}$ Dar kitoje apklausoje, kurią $2014 \mathrm{~m}$. sausio mèn. paskelbẻ Švedijos nenumatytų atvejų civilinëje srityje agentūra (MSB), 36 \% respondentų buvo už Švedijos narystę NATO, o $40 \%$ buvo prieš, tuo būdu, iš esmès parodydami statistines lygiąsias. ${ }^{61}$

Kitaip tariant, tikètina, kad drastiškai sumažinta gynybos struktūra, dalinai (ir iš esmès) pakeista saugumo politikos doktrina ir atsigaunanti, persiginkluojanti Rusija sąlygojo tai, kad labai išaugo švedų, pasisakančių už narystę NATO, skaičius, kuris pasieke tokị lygit, kad švedų, pasisakančiu už ir prieš, skaičius faktiškai tapo toks pat. Tai visiškai kitokia situacija palyginti su anksčiau aprašytu Suomijos atveju.

\section{Išvados}

Apibendrinant reikia pasakyti, kad Šiaurès ir Šiaurès ir Baltijos šalių bendradarbiavimas gynybos srityje plečiasi, tačiau problemų netrūksta, ir atrodo, kad bendradarbiavimas tarp Šiaurès šalių auga labiau negu Šiaurès ir Baltijos valstybių bendradarbiavimas. Tačiau išryškejjo tendencija, kad ŠB8 suvokia funkcionavimą kaip būdą transformuoti pačius Baltijos jūros regiono bendradarbiavimo modelius gynybos srityje.

Taip pat galima būtų pridurti, kad didžiulis sąsajų aplink Baltijos jūros regioną kompleksas - ekonominiu, politiniu, socialiniu ir kariniu požiūriu - sudaro visumą, kurią galima būtų pavadinti „saugumo kompleksu“: atskirų šalių saugumo problemos regione veikia visas kitas jame esančias šalis. Tai reiškia, kad ne tik tradiciniai probleminiai klausimai - tokie, kaip rusų mažumos Estijoje ir Latvijoje ir pan. - bet taip pat ir naujesni, kaip antai ŠB8 šalių bendros saugumo politikos strategijos nebuvimas - yra vis svarbesni visoms ŠB8 šalims.

\footnotetext{
${ }^{60}$ Žr. Claes Arvidsson (2012): Känsla och förnuft - opinioner om NATO [Feelings and rationality opinions about NATO], in Karlis Neretnieks [ed.] Nato - för och emot [NATO: Pro and Con] (Stockholm: Kungliga Krigsvetenskapsakademien/The Royal Academy of the War Sciences), pp. $133 \mathrm{ff}$. ${ }^{61}$ Žr. MSB (2014): Opinioner 2013 Allmänhetens syn på samhällsskydd, beredskap, säkerhetspolitik och försvar [Opinions 2013: The General Public's Views on Societal Security, Preparedness, Security Policy and Defence], http://rib.msb.se/Filer/pdf/27284.pdf, pp. 85ff.
} 
Tiesą sakant, ŠB8 saugumo politikos nenuoseklumas iš esmès kliudo ŠB8 šalims sukurti tikrą saugumo bendruomenę, kurioje abipusis pasitikèjimas būtų toks stiprus, kad bendras karinis planavimas atrodytų natūralus dalykas. Tai didžia dalimi jau vyksta tose ŠB8 šalyse, kurios priklauso NATO, bet kadangi dvi iš jų nepriklauso NATO, šio klausimo nebus galima tinkamai išspręsti dar ilgą laiką.

Visgi, narystės NATO klausimas dviejose Aljansui nepriklausančiose ŠB8 šalyse stipriai pasistūmèjo, tačiau labai skirtingai. Dèl to, kad gynybos politikoje neįvyko didelių pokyčiu ir nebuvo aiškių grèsmių, Suomijos naryste NATO yra mažiausiai tikètina. Kita vertus, dramatiški pokyčiai Švedijoje tiek gynybos ir saugumo politikoje, tiek juntamų grèsmių suvokimo atžvilgiu sąlygoja daug palankesnị požiūrị i narystę NATO, kuris jaučiamas plačiojoje visuomeneje ir parlamente. Galbūt, sprendimą tapti NATO nare Švedija priims tik po keleto metų, tačiau, turint omenyje pastarąsias visuomenès apklausas ir kintančias parlamentarų pažiūras, atrodo, kad šio sprendimo galutinis ịgyvendinimas yra tikètinas kaip niekada anksčiau. 